Open Access

\title{
Erratum to: Humanization of the mouse mammary gland by replacement of the luminal layer with genetically engineered preneoplastic human cells
}

Stephanie Verbeke ${ }^{1}$, Elodie Richard ${ }^{1}$, Elodie Monceau ${ }^{1}$, Xenia Schmidt ${ }^{1,2}$, Benoit Rousseau ${ }^{3}$, Valerie Velasco ${ }^{1,4}$, David Bernard ${ }^{5}$, Herve Bonnefoi ${ }^{1}$, Gaetan MacGrogan ${ }^{1,4}$ and Richard D $\operatorname{lgg} 0^{1,2^{*}}$

\section{Erratum}

Due to a typesetting error, the labelling was changed and the figures in this article [1] were presented in the order 2 , $4,10,6,1,3,5,7,8,9,11,12,13,14$ and the supplementary figure links were inverted. The revised version has the figures in the correct order.

\begin{abstract}
Author details
'INSERM U916, Bergonié Cancer Institute, University of Bordeaux, 229 cours de l'Argonne, Bordeaux 33076, France. ${ }^{2}$ School of Medicine, University of St Andrews, Medical and Biological Sciences Building, North Haugh, St Andrews KY16 9TF, UK. ${ }^{3}$ Animalerie A2, University of Bordeaux, 146 rue Léo Saignat, Bordeaux 33076, France. ${ }^{4}$ Pathology Department, Bergonié Cancer Institute, 229 cours de l'Argonne, Bordeaux 33076, France. ${ }^{5}$ INSERM U1052, Centre Leon Berard, University of Lyon, 28 rue Laennec, Lyon 69008, France.
\end{abstract}

Received: 8 July 2015 Accepted: 8 July 2015

Published online: 16 September 2015

\section{Reference}

1. Verbeke S, Richard E, Monceau E, Schmidt X, Rousseau B, Velasco V, et al. Breast Canc Res. 2014;16:504

\footnotetext{
* Correspondence: r.iggo@bordeaux.unicancer.fr

'INSERM U916, Bergonié Cancer Institute, University of Bordeaux, 229 cours de l'Argonne, Bordeaux 33076, France

${ }^{2}$ School of Medicine, University of St Andrews, Medical and Biological

Sciences Building, North Haugh, St Andrews KY16 9TF, UK

Full list of author information is available at the end of the article
}

Submit your next manuscript to BioMed Central and take full advantage of:

- Convenient online submission

- Thorough peer review

- No space constraints or color figure charges

- Immediate publication on acceptance

- Inclusion in PubMed, CAS, Scopus and Google Scholar

- Research which is freely available for redistribution

Submit your manuscript at

www.biomedcentral.com/submit

() Biomed Central 